\title{
The Effect of High Temperature Occurring in Subsequent Stages of Plant Development on Potato Yield and Tuber Physiological Defects
}

\author{
Krystyna Rykaczewska
}

Published online: 11 February 2015

(C) The Author(s) 2015. This article is published with open access at Springerlink.com

\begin{abstract}
Potato (Solanum tuberosum L.) is characterized by specific temperature requirements and develops best at about $20^{\circ} \mathrm{C}$. High temperatures during the growing season cause an array of changes in potato plants, which affect its development and may lead to a drastic reduction in economic yield. In natural conditions drought and heat stress are two different types of abiotic stresses that occur in the field simultaneously or separately, in the case of irrigation use on potato plantations. The aim of this work was to assess the response of six potato cultivars to high temperature during the subsequent stages of plant growth under conditions of good soil moisture and drought. The pot experiment was carried out with the cultivars: Aruba, Desirée, Etola, Finezja, Flaming and Tetyda. The impact of high temperature day/ night $35{ }^{\circ} \mathrm{C} / 25{ }^{\circ} \mathrm{C}$ on potato plants was tested in three periods: June 16-30, July 115 and July 16-30. In these periods half of the plants were watered to a level close to optimal, while the other half remained without irrigation. Final harvest was performed after full maturity of plants in the control combination. Our studies confirm the view that potato productivity is greatly reduced at temperatures higher than optimum. Here we demonstrated that tested potato cultivar's response to high temperature during the growing season is dependent on the growth stage. The earlier a heat occurs, the more negative its impact on the growth and total yield of potatoes. The results obtained in this study indicate that among the tested cultivars 'Tetyda' was the most tolerant to high temperature acting on the plants during the growing season. Our research shows that the total yield is not
\end{abstract}

K. Rykaczewska $(\square)$

Department of Potato Agronomy, Plant Breeding and

Acclimatization Institute - National Research Institute,

Jadwisin, 05-140 Serock, Poland

e-mail: k.rykaczewska@ihar.edu.pl the only indicator of potato tolerance to high temperature during the growing season, but the assessment should also take into account the occurrence of secondary tuberization and physiological defects of tubers.

Resumen La papa (Solanum tuberosum L.) se caracteriza por requerimientos específicos de temperatura y se desarrolla mejor a cerca de $20^{\circ} \mathrm{C}$. Las altas temperaturas durante el ciclo del cultivo causa un arreglo de cambios en las plantas, que afecta su desarrollo y pudiera conducir a reducción drástica en el rendimiento económico. En condiciones naturales la sequía y el agobio térmico son dos tipos diferentes de agobios abióticos que se presentan en el campo simultáneamente o por separado, en el caso de siembras de papa de riego. El propósito de este trabajo fue evaluar la respuesta de seis variedades de papa a la alta temperatura durante los estados subsecuentes de crecimiento de la planta bajo condiciones de buena humedad del suelo y bajo sequía. El experimento en macetas se desarrolló con las variedades Aruba, Desirée, Etola, Finezja, Flaming y Tetyda. Se probó el impacto de la alta temperatura día/noche $35^{\circ} \mathrm{C} / 25^{\circ} \mathrm{C}$ en plantas de papa en tres períodos: junio 16-30, julio 1-15 y julio 16-30. En estos lapsos la mitad de las plantas se regaron a un nivel cercano a lo óptimo, mientras que la otra mitad permaneció sin riego. La cosecha final se efectuó después de la madurez completa de las plantas en la combinación testigo. Nuestros estudios confirman la visión de que la productividad de la papa se reduce grandemente a temperaturas más altas a la óptima. Aquí demostramos que la respuesta a la alta temperatura de las variedades de papa probadas durante el ciclo de cultivo depende del estado de crecimiento. Entre más temprano se presenta el calor, es más negativo su impacto en el crecimiento y rendimiento total de papas. Los resultados obtenidos en este estudio indican que entre las variedades probadas, Tetyda fue la más tolerante a la alta temperatura sobre las plantas durante 
el ciclo de cultivo. Nuestra investigación muestra que el rendimiento total no es el único indicador de la tolerancia de la papa a alta temperatura durante la época del crecimiento, la evaluación debería también tomar en cuenta la presencia de tuberización secundaria y los defectos fisiológicos de tubérculos.

Keywords Drought $\cdot$ Secondary tuberization $\cdot$ Chlorophyll $a$ fluorescence

\section{Introduction}

Potato (Solanum tuberosum L) is a plant typical mainly of temperate climate. The crop grows best in cool but frost-free seasons and does not perform well in heat (Bodlaender 1963; Bodlaender et al. 1964; Hijmans 2003). It is characterized by specific temperature requirements. The limits and optimal values for the growth of the above-ground part of the potato plant and for the tubers are different (Marinus and Bodlaender 1975; Struik et al. 1989a; 1989b; Rykaczewska 1993; Van Dam et al. 1996). From experiments conducted in growth chambers it is known that haulm growth is fastest in the temperature range of $20-25{ }^{\circ} \mathrm{C}$ whereas the optimal range for tuberization and tuber growth is $15-20^{\circ} \mathrm{C}$. Under hightemperature conditions, tuberization is significantly inhibited and photoassimilate partitioning to tubers is greatly reduced (Ewing 1981; Haynes et al. 1989; Krauss and Marschner 1984; Lafta and Lorenzen 1995). Heat stress due to increased temperature is an agricultural problem in many areas in the world (Birch et al. 2012). Transitory or constant high temperatures cause an array of morpho-anatomical, physiological and biochemical changes in plants, which affect plant growth and development and may lead to a drastic reduction in economic yield (Wahid et al. 2007). The adverse effects of heat stress can be mitigated by developing potato plants with improved thermotolerance using various genetic approaches (Levy et al. 1991; Veilleux et al. 1997). For this task, however, a thorough understanding of physiological responses of plants to high temperature is imperative.

In natural conditions drought and heat stress are two different types of abiotic stresses that occur generally in the field simultaneously. Due to increasing irrigation use on potato plantations and periodic action of heat stress under conditions of good soil moisture, in some studies the impact of high temperature on potato plants was separated from the impact of drought (Rykaczewska 2004a, b, c). According to De Temmerman et al. (2002) it is not clear if the whole growing period is important for potato or if the time between maximum leaf area, coinciding with the stage of flowering and harvest, is the most sensitive period. Generally there is not much information on the effect of heat and drought stress at different stages of potato tuber growth (Levy 1985; Levy and Veilleux 2007).

The aim of this work was to assess the response of selected potato cultivars to high temperature during the subsequent stages of plant growth under soil moisture conditions favourable to plants and under drought conditions.

\section{Materials and Methods}

\section{Tested Cultivars and Treatments}

The pot experiment was carried out in open area next to a greenhouse and in a growth chamber, over the course of 2 years 2010-2011. The following early cultivars were tested: Flaming (very early), Aruba, Etola (early), Finezja, Tetyda (medium early) and the cultivar Desirée (medium early) with very high adaptability to the environment (EPCD 2008). The first five cultivars came from Polish Potato Breeding Zamarte Ltd., Co. IHAR Group and the sixth from the Potato Gene Bank (IHAR-NIR).

The impact of high temperature day/night $35^{\circ} \mathrm{C} / 25^{\circ} \mathrm{C}$ on potato plants was tested in three periods: I-June 16-30, IIJuly $1-15$ and III- July $16-30$. In these periods half of the plants were watered to a level close to optimal (Favourable Soil Moisture), while the other half remained without irrigation (Soil Drought). The control combination consisted of potato plants grown throughout the whole season under conditions close to optimal.

\section{Weather Conditions}

Weather conditions during the years of study were monitored using a Campbell Weather Station (Campbell Scientific Inc.) located adjacent to the greenhouse and additionally using a thermohigrograph placed between pots. The two most important meteorological factors, air temperature and the photosynthetically active radiation, were similar in the years of study and favourable for potato development (Table 1).

\section{Seed Material and Planting}

In the spring minitubers were selected and those of the size 3$4 \mathrm{~cm}$ (transverse diameter) were pre-sprouted for 5 weeks and next used for planting. They were planted in 10-liter pots filled with a thin layer of gravel and soil which is the standard substrate for vegetables. The number of objects (pots) was a total of 198, and each cultivar accounted for 33. Dates of planting were April 23-24. The pots with plants were set on special tables on wheels and were moved outdoor, adjacent to the greenhouse. The density of pots was 4 per $\mathrm{m}^{2}$. 
Table 1 Mean values of air temperature and photosynthetically active radiation (PAR) during growing season in the years of study

\begin{tabular}{|c|c|c|c|c|c|c|c|}
\hline \multirow[t]{2}{*}{ Meteorolgical Factor } & \multirow[t]{2}{*}{ Year } & \multirow[t]{2}{*}{ Decade } & \multicolumn{4}{|l|}{ Month } & \multirow[t]{2}{*}{ Mean } \\
\hline & & & May & June & July & August & \\
\hline \multirow[t]{8}{*}{ Temperaturein ${ }^{\circ} \mathrm{C}$} & \multirow[t]{4}{*}{2010} & I & 10.7 & 18.1 & 17.4 & 19.4 & \multirow[t]{4}{*}{$16.9 \mathrm{a}$} \\
\hline & & II & 12.7 & 16.7 & 23.4 & 20.1 & \\
\hline & & III & 13.6 & 15.6 & 19.3 & 16.0 & \\
\hline & & mean & 12.3 & 16.8 & 20.0 & 18.5 & \\
\hline & \multirow[t]{4}{*}{2011} & I & 8.0 & 19.2 & 15.7 & 17.6 & \multirow[t]{5}{*}{$16.3 \mathrm{a}$} \\
\hline & & II & 14.6 & 16.4 & 18.9 & 17.5 & \\
\hline & & III & 16.6 & 16.8 & 16.4 & 17.5 & \\
\hline & & mean & 13.1 & 17.5 & 17.0 & 17.5 & \\
\hline mean & & & $12.7 \mathrm{~b}$ & $17.1 \mathrm{a}$ & $18.5 \mathrm{a}$ & $18.0 \mathrm{a}$ & \\
\hline \multirow{8}{*}{$\begin{array}{l}\text { PAR } \\
\text { in } \\
\mathrm{J}^{-1} \mathrm{~m}^{-1} \mathrm{sec}^{1}\end{array}$} & \multirow[t]{4}{*}{2010} & I & 206 & 430 & 452 & 374 & \multirow[t]{4}{*}{$354 \mathrm{a}$} \\
\hline & & II & 229 & 426 & 447 & 358 & \\
\hline & & III & 360 & 405 & 297 & 263 & \\
\hline & & mean & 265 & 420 & 399 & 332 & \\
\hline & \multirow[t]{4}{*}{2011} & I & 336 & 432 & 234 & 321 & \multirow[t]{4}{*}{$358 \mathrm{a}$} \\
\hline & & II & 380 & 379 & 378 & 348 & \\
\hline & & III & 436 & 475 & 227 & 352 & \\
\hline & & mean & 384 & 429 & 380 & 340 & \\
\hline mean & & & $325 \mathrm{a}$ & $424 \mathrm{a}$ & $339 \mathrm{a}$ & $336 \mathrm{a}$ & \\
\hline
\end{tabular}

Explanations:

a, b mean values followed by the same letters are not significantly different at the 0.05 level according Tukey's test

Proceeding with Plants during the Growing Season

Throughout the growing season the plants were carefully tended daily and regularly watered at a level close to optimum. Soil moisture was measured using the Soil Moisture Meter (Bioterm 812, PL). Recommended plant protection products were used to control diseases and pests. Just before the start of the heat treatmet, six plants of each cultivar were transferred to a growth chamber for a period of 15 days. Phenological stages of plants of tested cultivars just before high temperature treatment in different periods of growing season are presented in Table 2. Conditions in the growth chamber were: photoperiod

Table 2 Stages of plant development just before the impact of high temperatures in subsequent periods of growing season - mean values for tested cultivars

\begin{tabular}{lllll}
\hline $\begin{array}{l}\text { Period of } \\
\text { HT* }\end{array}$ & DAP** & $\begin{array}{l}\text { Phenological } \\
\text { stage }\end{array}$ & LAI*** & $\begin{array}{l}\text { Tuber fresh } \\
\text { weight/ plant } \\
\text { in } \mathrm{g}\end{array}$ \\
\hline I & $51-65$ & flowering & $2.69 \mathrm{a}$ & $443 \mathrm{c}$ \\
II & $65-79$ & development of fruits & $2.72 \mathrm{a}$ & $886 \mathrm{~b}$ \\
III & $80-94$ & beginning of maturity & $1.97 \mathrm{~b}$ & $1169 \mathrm{a}$ \\
\hline
\end{tabular}

Explanations:

*high temperature, $* *$ days after planting. ***leaf area index

$a, b$ mean values followed by the same letters are not significantly different at the 0.05 level according Tukey's test
15 h, lighting with Philips SON-T Agro $400 \mathrm{~W}$ lamps (100$120 \mathrm{Wm}^{-2}$ at $\left.1.5 \mathrm{~m}\right)$. The temperature was maintained at a level established by experiment $\left(35^{\circ} \mathrm{C} / 25^{\circ} \mathrm{C}\right)$. Half of the plants were watered regularly to a level close to the optimum (Favourable Soil Moisture), and the other half were subjected to soil drought by ceasing watering (Soil Drought). After the end of high temperature periods, measurements of plant height and chlorophyll $a$ fluorescence were performed. Then plants were moved outdoors where further development under conditions close to optimal took place. Chlorophyll $a$ fluorescence measurements were performed on the plants with a Pocket PEA (Plant Efficiency Analyzer, Hansatech, UK). The youngest leaves ( 3 per plant) were kept in darkness for at least $20 \mathrm{~min}$ in specially provided clips. Determined parameters were: PI - Performance Index of photosystem II (PS II) in relative units and $\mathrm{Fv} / \mathrm{Fm}$ - the photochemical efficiency of photosystem II. Here only the first parameter is presented.

\section{Final Yield}

Final harvest was performed after full maturity of plants in the control combination, between August 16 and 25. The total mass and number of tubers per plant were determined and the mass of individual tubers was calculated. The presence of physiological defects in the tubers, mainly deformations (gemmations, elongated tubers, bottlenecks, chain-tuberization) and sprouting were determined as a percentage of the total mass of tubers. 
Measures of tolerance of the potato cultivars to high temperature during the growing season were a decrease in yield, number of tubers per plant and the presence of physiological defects in the tubers in relation to the control combination.

\section{Data Analysis}

The results of the experiments were analyzed with ANOVA using a general linear model of statistics program in SAS Enterprise Guide 4 (2004). Means were separated with Tukey's test at $5 \%$ p-value.

\section{Results and Discussion}

Significant impacts of the tested factors on the height of plants, chlorophyll $a$ fluorescence in leaves, yield, number of tubers, mass of individual tuber, tubers deformations and sprouted tubers were found (Table 3).

Height of Plants and Chlorophyll $a$ fluorescence in Leaves Immediately after the Impact of High Temperature

In the first and second period of high temperature under favourable soil moisture conditions, the plants of all cultivars responded with an increase in height (Fig. 1, Tables 4 and 5). The results are consistent with the results of previous studies whereby a temperature higher than optimal intensified development of the aboveground part of plants (Bodlaender 1963; Benoit et al. 1983; Struik et al. 1989a; Gawrońska et al. 1992; Kooman and Haverkort 1995; Van Dam et al. 1996; Rykaczewska 2013b). Our work additionally shows that the increase in plant height was greater the earlier they were exposed to heat. Due to the limited number of plants in the experiment, measurement of the mass of the aboveground part of plants was not performed.

The performance index of photosystem II (PI), parameter of chlorophyll $a$ fluorescence, gave a clearer picture of the physiological status of plants at the time just after the periods of high temperature treatment. High temperature under drought conditions negatively influenced PI activity in tested plants, and its effect was dependent on the period of stress application and on the cultivar (Fig. 1, Table 6). The negative impact of high temperature on plants growing under conditions of good soil moisture was much weaker. In the second half of June, when the plants were physiologically younger, the value of Performance Index was even close to the control (Tables 4 and 6). The value of this indicator was the largest in cultivar Finezja and also 'Desirée', with a very high adaptability to the environment. The other cultivars stand out with

Table 3 Significance level of tested factors - from the analysis of variance

\begin{tabular}{|c|c|c|c|c|c|c|c|c|}
\hline \multirow[t]{2}{*}{ Characteristics } & \multicolumn{8}{|c|}{ Source of variation } \\
\hline & soil moisture & period of HT & cultivar & year & $\begin{array}{l}\text { soil moisture } \\
\mathrm{x} \text { period }\end{array}$ & $\begin{array}{l}\text { soil moist.x } \\
\text { cultivar }\end{array}$ & $\begin{array}{l}\text { period } \mathrm{x} \\
\text { cultivar }\end{array}$ & $\begin{array}{l}\text { soil } x \\
\text { period } x \text { cult }\end{array}$ \\
\hline \multicolumn{9}{|l|}{ Plants in control } \\
\hline Height in $\mathrm{cm}$ & & & 0.0005 & 0.24 & & & & \\
\hline PI - I HT period & & & 0.70 & 0.014 & & & & \\
\hline PI - II HT period & & & 0.92 & 0.014 & & & & \\
\hline PI - III HT period & & & 0.92 & 0.032 & & & & \\
\hline \multicolumn{9}{|c|}{ Plants after stresses } \\
\hline Height in \% & $<0.0001$ & $<0.0001$ & $<0.0001$ & 0.11 & $<0.0001$ & 0.02 & 0.0004 & 0.002 \\
\hline P.I. & $<0.0001$ & $<0.0001$ & $<0.0001$ & 0.06 & $<0.0001$ & $<0.0001$ & 0.0005 & 0.07 \\
\hline \multicolumn{9}{|c|}{ Final yield in control } \\
\hline Yield g/plant & - & - & 0.035 & 0,89 & - & - & - & - \\
\hline Tuber number & - & - & 0.30 & 0,02 & - & - & - & - \\
\hline Tuber size in $g$ & - & - & 0.53 & 0.04 & - & - & - & - \\
\hline \multicolumn{9}{|l|}{ Final yield in \% } \\
\hline Yield & $<0.0001$ & $<0.0001$ & 0.0002 & 0.06 & $<0.0001$ & 0.13 & 0.40 & 0.61 \\
\hline Tuber number & $<0.0001$ & $<0.0001$ & $<0.0001$ & 0.30 & 0.10 & 0.07 & 0.03 & 0.15 \\
\hline Mass of 1 tuber & 0.33 & $<0.0001$ & $<0.0001$ & 0.98 & 0.20 & 0.08 & 0.49 & 0.30 \\
\hline Deformations & $<0.0001$ & $<0.0001$ & $<0.0001$ & 0.08 & 0.09 & $<0.0001$ & $<0.0001$ & $<0.0001$ \\
\hline Sprouted tubers & 0.21 & $<0.0001$ & $<0.0001$ & 0.052 & 0.12 & 0.22 & $<0.0001$ & 0.64 \\
\hline
\end{tabular}

Explanations:

$H T$ high temperature; level $P<0.05$ - differences statistically significant 
Fig. 1 Height of plants in relation to the control and Performance Index of photosystem II (PI) just after the periods of HT depending on soil moisture, the period of high temperature and cultivars. Explanations: $H T$ high temperature, FSM favourable soil moisture; $S D$ soil drought; $a, b, c$ mean values followed by the same letters are not significantly different at the 0.05 level according Tukey's test; r.u. relative unit; comma on the $\mathrm{Y}$ axis is instead dot

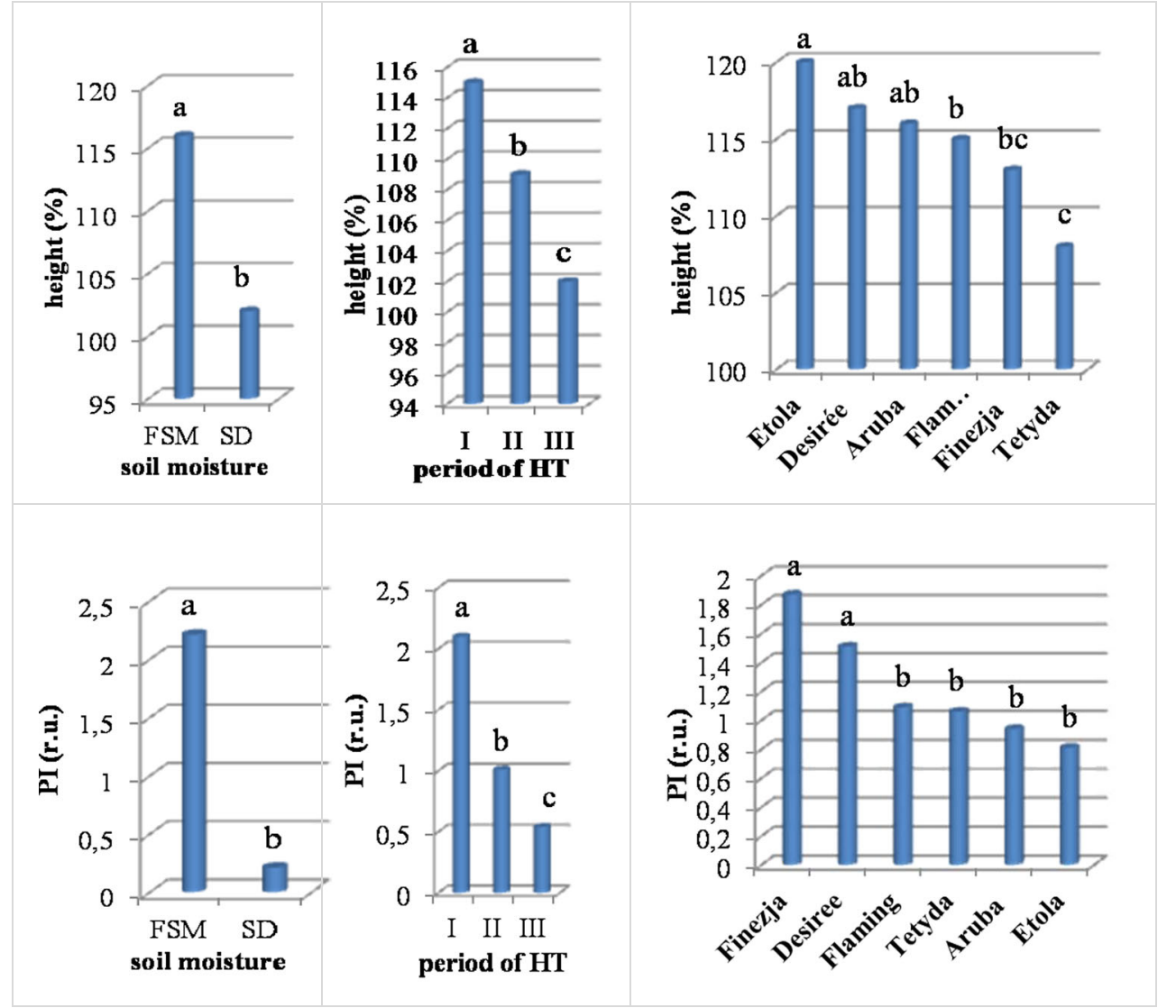

significantly lower PI. The obtained results indicate the dependency of Performance Index of photosystem II on the physiological age of potato plants. Fluorescence sensing methods have been used to monitor crop physiology for years
(Lichtenthaler and Miehé 1997; Tremblay et al. 2012; Kalaji et al. 2012), however, in the literature, there is little information on the fluorescence of chlorophyll $a$ in leaves of potato plants, especially in the context of the comparison cultivars'

Table 4 Characteristics of plants and final yield of tested cultivars in the control

\begin{tabular}{|c|c|c|c|c|c|c|c|}
\hline \multirow[t]{2}{*}{ Cultivar } & \multirow[t]{2}{*}{$\begin{array}{l}\text { Height of plants in } \\
\text { the end of June* in } \mathrm{cm}\end{array}$} & \multicolumn{3}{|c|}{$\begin{array}{l}\text { P.I. (index of chlorophyll } a \\
\text { fluorescence) after HT** periods }\end{array}$} & \multirow[t]{2}{*}{ Yield g/ plant } & \multirow[t]{2}{*}{$\begin{array}{l}\text { Number } \\
\text { of tubers }>1 \mathrm{~cm} / \text { plant }\end{array}$} & \multirow[t]{2}{*}{$\begin{array}{l}\text { Mass of tubers }>1 \\
\mathrm{~cm} \text { in } \mathrm{g}\end{array}$} \\
\hline & & I & II & III & & & \\
\hline Aruba & $60.0 \mathrm{ab}$ & $2.41 \mathrm{a}$ & $1.72 \mathrm{a}$ & $0.68 \mathrm{a}$ & $1344 \mathrm{ab}$ & 36 & 39 \\
\hline Desirée & $43.0 \mathrm{c}$ & $1.52 \mathrm{a}$ & $1.35 \mathrm{a}$ & $0.71 \mathrm{a}$ & $1309 a b$ & 33 & 40 \\
\hline Etola & $65.5 \mathrm{a}$ & $1.63 \mathrm{a}$ & $1.44 \mathrm{a}$ & $0.40 \mathrm{a}$ & $1260 \mathrm{~b}$ & 42 & 30 \\
\hline Finezja & $58.0 \mathrm{ab}$ & $2.22 \mathrm{a}$ & $1.90 \mathrm{a}$ & $0.49 \mathrm{a}$ & $1372 a b$ & 33 & 43 \\
\hline Flaming & $53.5 \mathrm{~b}$ & $2.44 \mathrm{a}$ & $1.99 \mathrm{a}$ & $0.76 \mathrm{a}$ & $1440 a b$ & 40 & 37 \\
\hline Tetyda & $61.0 \mathrm{ab}$ & $1.84 \mathrm{a}$ & $2.24 \mathrm{a}$ & $0.87 \mathrm{a}$ & $1508 \mathrm{a}$ & 35 & 40 \\
\hline Mean & 56.8 & 2.01 & 1.78 & 0.63 & 1372 & 36 & 38 \\
\hline 2010 & $57.5 \mathrm{a}$ & $1.23 \mathrm{~b}$ & $0.75 \mathrm{~b}$ & $0.28 \mathrm{~b}$ & 1374 & $41 \mathrm{a}$ & $33 \mathrm{~b}$ \\
\hline 2011 & $56.2 \mathrm{a}$ & $2.78 \mathrm{a}$ & $2.80 \mathrm{a}$ & $0.90 \mathrm{a}$ & 1370 & $32 \mathrm{~b}$ & $43 \mathrm{a}$ \\
\hline
\end{tabular}

Explanations:

*after the end of growth

**high temperature

a, b mean values followed by the same letters are not significantly different at the 0.05 level according Tukey's test 
Table 5 Height of plants of tested cultivars in relation to the control depending on the period of high temperature and soil moisture and cultivar - in \%

\begin{tabular}{|c|c|c|c|c|c|c|c|c|c|}
\hline \multirow[t]{3}{*}{ Cultivar } & \multicolumn{9}{|c|}{ Period of high temperature } \\
\hline & \multicolumn{3}{|l|}{ I } & \multicolumn{3}{|l|}{ II } & \multicolumn{3}{|l|}{ III } \\
\hline & FSM* & $\mathrm{SD}^{* *}$ & mean & FSM* $^{*}$ & $\mathrm{SD}^{* *}$ & mean & FSM* $^{*}$ & $\mathrm{SD}^{* *}$ & mean \\
\hline Aruba & 128 & 103 & $116 a b$ & 125 & 106 & $116 \mathrm{a}$ & 116 & 99 & $108 \mathrm{a}$ \\
\hline Desireée & 131 & 102 & $117 \mathrm{ab}$ & 115 & 101 & $108 \mathrm{bc}$ & 101 & 103 & $102 \mathrm{~b}$ \\
\hline Etola & 135 & 105 & $120 \mathrm{a}$ & 116 & 101 & $109 \mathrm{bc}$ & 103 & 100 & $102 \mathrm{~b}$ \\
\hline Finezja & 125 & 101 & $113 \mathrm{bc}$ & 120 & 102 & $111 \mathrm{ab}$ & 98 & 98 & $98 \mathrm{c}$ \\
\hline Flaming & 127 & 102 & $115 \mathrm{bc}$ & 110 & 100 & $105 \mathrm{c}$ & 102 & 99 & $101 \mathrm{~b}$ \\
\hline Tetyda & 114 & 101 & $108 \mathrm{c}$ & 118 & 99 & $109 \mathrm{bc}$ & 103 & 100 & $102 \mathrm{~b}$ \\
\hline mean & $127 \mathrm{a}$ & $102 \mathrm{~b}$ & $115 \mathrm{a}$ & $117 \mathrm{a}$ & $103 \mathrm{~b}$ & $109 \mathrm{~b}$ & $104 \mathrm{a}$ & $100 \mathrm{a}$ & $102 \mathrm{c}$ \\
\hline
\end{tabular}

Explanations:

*favourable soil moisture

**soil drought

$\mathrm{a}, \mathrm{b}$ mean values followed by the same letters are not significantly different at the 0.05 level according Tukey's test

response to the high temperature impact (Jefferies 1992; Mauromicale et al. 2006).

\section{Final Yield}

The final yield of tested cultivars and the number of tubers in control were relatively high (Table 4). Tuber mass per plant was about twice that in the experiment of Levy (1985) but individual tuber weight was similar. This indicates more intense tuberization under temperate climate conditions than in a semi-arid Mediterranean climate. In our experience, there were normal differences between cultivars, which are the result of their ability to yield and physiological seed vigor in a given environment (Rykaczewska 2013a). The higher number of tubers in the first year was likely due to the slightly more favourable conditions for potato tuber development.

The high temperature during the growing season had a negative effect on the final yield of tested cultivars (Fig. 2, Table 7). The effect was strongest when the high temperature influenced plants in the second half of June (period I). In this period the decrease in the relative yield was an average $24 \%$ but the effect was stronger in the case of combined effects of high temperature and drought compared to high temperature under favourable soil moisture conditions. When the time of high temperature treatment on potato plants was delayed (II and III period), the negative effect on the yield of tubers became weaker, but the differences between the combinations of "favorable soil moisture" and "drought" remained statistically significant. There were no significant differences between

Table 6 Performance Index of photosystem II just after high temperature impact depending on cultivar, period and soil moisture - in relative units

\begin{tabular}{|c|c|c|c|c|c|}
\hline \multirow[t]{2}{*}{ Cultivar } & \multicolumn{3}{|c|}{ Period of high temperature } & \multicolumn{2}{|c|}{ Soil moisture } \\
\hline & I & II & III & $\mathrm{FSM}^{*}$ & $\mathrm{SD}^{* *}$ \\
\hline Aruba & $1.61 \mathrm{c}$ & $0.61 \mathrm{c}$ & $0.60 \mathrm{ab}$ & $1.78 \mathrm{c}$ & $0.09 \mathrm{~b}$ \\
\hline Desireée & $2.80 \mathrm{~b}$ & $1.43 \mathrm{a}$ & $0.30 \mathrm{~b}$ & $2.57 \mathrm{~b}$ & $0.45 \mathrm{ab}$ \\
\hline Etola & $1.33 \mathrm{c}$ & $0.70 \mathrm{~b}$ & $0.41 \mathrm{ab}$ & $1.47 \mathrm{c}$ & $0.15 \mathrm{~b}$ \\
\hline Finezja & $3.11 \mathrm{a}$ & $1.56 \mathrm{a}$ & $0.95 \mathrm{a}$ & $3.39 \mathrm{a}$ & $0.90 \mathrm{a}$ \\
\hline Flaming & $2.09 \mathrm{~b}$ & $0.71 \mathrm{~b}$ & $0.49 \mathrm{ab}$ & $2.09 \mathrm{~b}$ & $0.10 \mathrm{~b}$ \\
\hline \multirow[t]{2}{*}{ Tetyda } & $1.65 \mathrm{c}$ & $1.03 \mathrm{bc}$ & $0.51 \mathrm{ab}$ & $2.00 \mathrm{bc}$ & $0.12 \mathrm{~b}$ \\
\hline & $\begin{array}{l}\text { FSM }-3,70 a \\
S D-0.49 b\end{array}$ & $\begin{array}{l}\text { FSM }-1,86 \mathrm{a} \\
\mathrm{SD}-0.15 \mathrm{~b}\end{array}$ & $\begin{array}{l}\text { FSM }-1,08 \mathrm{a} \\
\mathrm{SD}-0.00 \mathrm{a}\end{array}$ & & \\
\hline
\end{tabular}

Explanations:

*favourable soil moisture

**soil drought

$\mathrm{a}, \mathrm{b}$ mean values followed by the same letters are not significantly different at the 0.05 level according Tukey's test 
Fig. 2 The final yield, number of tubers and an average mass of individual tuber of tested cultivars in relation to the control depending on cultivar, period of high temperature and soil moisture. Explanations: $H T$ high temperature, FSM favourable soil moisture, $S D$ soil drought; $a, b, c$ mean values followed by the same letters are not significantly different at the 0.05 level according Tukey's test

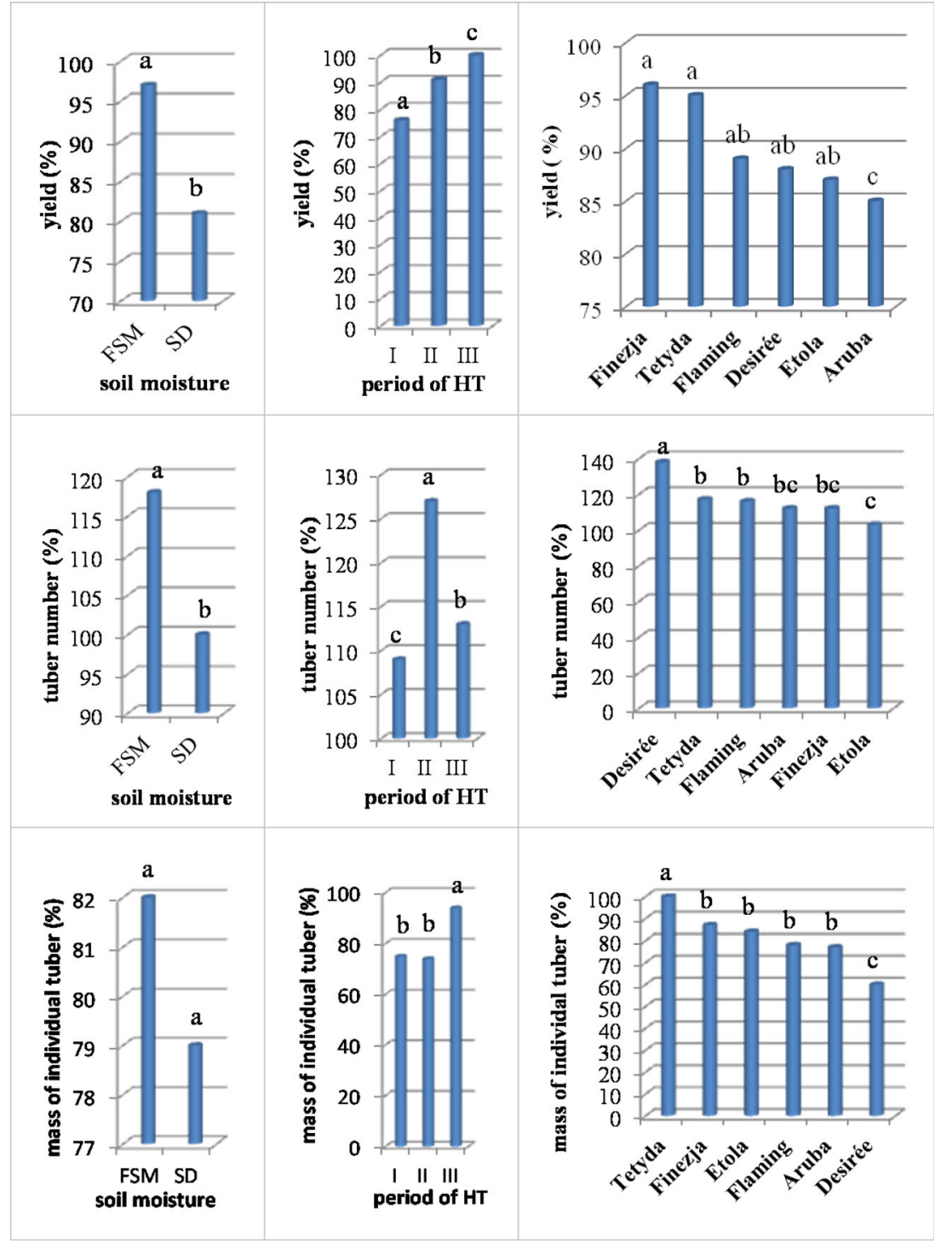

cultivars regarding the period of impact of heat stress or soil moisture, which indicates a generalized effect (Table 3). Among the most tolerant from the viewpoint of decrease in

Table 7 The final yield in relation to the control depending on the period of high temperature impact and soil moisture - mean value for tested cultivars $(\%)$

\begin{tabular}{llll}
\hline Soil moisture & \multicolumn{4}{l}{ Period of high temperature } \\
\cline { 2 - 4 } & I & II & III \\
\hline FSM $^{*}$ & $88 \mathrm{a}$ & $101 \mathrm{a}$ & $103 \mathrm{a}$ \\
SD $^{* *}$ & $64 \mathrm{~b}$ & $80 \mathrm{~b}$ & $97 \mathrm{a}$ \\
\hline
\end{tabular}

Explanations:

*favourable soil moisture

$* *$ soil drought

$\mathrm{a}, \mathrm{b}$ mean values followed by the same letters are not significantly different at the 0.05 level according Tukey's test yield were 'Finezja' and 'Tetyda'. In the study of Levy (1986a, 1986b) heat stress reduced tuber yields of ten tested potato genotypes from zero to $96 \%$ but the experiment was conducted under natural conditions in a semi-arid environment and a comparison was made between two cycles of vegetation, between the spring cycle under favourable climatological conditions and the summer cycle under high temperature conditions. Additionally in his study the seeds differed in physiological age.

The number of tubers in the final yield of tested cultivars was significantly dependent on the soil moisture during the impact of high temperature (Fig. 2, Table 8). Here we show that soil moisture favourable for plants led to an increase of the number of tubers. However, the experiment conducted by Bodlaender et al. (1964) showed that high temperature induces second-growth in potato tubers irrespective of the water supply and that drought is not necessary to induce the secondgrowth. In our experiment the largest increases in the number 
Table 8 The number of tubers of tested cultivars in relation to the control depending on the period of high temperature and soil moisture in $\%$

\begin{tabular}{llll}
\hline Cultivar & \multicolumn{2}{l}{ Period of high temperature } \\
\cline { 2 - 4 } & I & II & III \\
\hline Aruba & $108 \mathrm{~b}$ & $124 \mathrm{~b}$ & $106 \mathrm{~b}$ \\
Desirée & $130 \mathrm{a}$ & $143 \mathrm{a}$ & $143 \mathrm{a}$ \\
Etola & $99 \mathrm{c}$ & $106 \mathrm{c}$ & $106 \mathrm{~b}$ \\
Finezja & $105 \mathrm{~b}$ & $125 \mathrm{~b}$ & $107 \mathrm{~b}$ \\
Flaming & $107 \mathrm{~b}$ & $129 \mathrm{~b}$ & $113 \mathrm{~b}$ \\
Tetyda & $105 \mathrm{~b}$ & $140 \mathrm{a}$ & $107 \mathrm{~b}$ \\
\hline
\end{tabular}

Explanations:

$a, b$ mean values followed by the same letters are not significantly different at the 0.05 level according Tukey's test

of tubers occurred when the high temperature affected the plants in the first half of July (period II). This points to the secondary tuberization in tested cultivars. The highest increase was seen in the cultivar Desirée. A similar phenomenon was observed by Levy (1985) who studied two cultivars, Desirée and Cara, and found that the number of tubers per plant tended to increase in heat treatment more intensively in 'Desirée'. Biochemical studies of the relationship between thermotolerance and heat-shock protein expression in potato, conducted by Ahn et al. (2004) indicate a lack of high tolerance of
Table 9 Physiological deformations of tubers of individual cultivars depending on high temperature during growing season and soil moisture - in $\%$ of total yield

Cultivar Period of high temperature

\begin{tabular}{lll}
\hline I & II & III \\
\cline { 1 - 1 } &
\end{tabular}

\begin{tabular}{llllllllll}
\hline Aruba & $0 \mathrm{~b}$ & $0 \mathrm{c}$ & $0 \mathrm{c}$ & $0 \mathrm{c}$ & $0 \mathrm{~b}$ & $0 \mathrm{c}$ & $0 \mathrm{c}$ & $0 \mathrm{~b}$ & $0 \mathrm{~b}$ \\
Desiree & $34 \mathrm{a}$ & $14 \mathrm{~b}$ & $24 \mathrm{~b}$ & $23 \mathrm{ab}$ & $9 \mathrm{~b}$ & $16 \mathrm{~b}$ & $12 \mathrm{~b}$ & $12 \mathrm{a}$ & $12 \mathrm{a}$ \\
Etola & $22 \mathrm{ab}$ & $2 \mathrm{c}$ & $12 \mathrm{bc}$ & $14 \mathrm{~b}$ & $2 \mathrm{~b}$ & $8 \mathrm{bc}$ & $14 \mathrm{~b}$ & $4 \mathrm{ab}$ & $9 \mathrm{a}$ \\
Finezja & $39 \mathrm{a}$ & $40 \mathrm{a}$ & $40 \mathrm{a}$ & $35 \mathrm{a}$ & $25 \mathrm{a}$ & $30 \mathrm{a}$ & $26 \mathrm{a}$ & $8 \mathrm{ab}$ & $17 \mathrm{a}$ \\
Flaming & $0 \mathrm{~b}$ & $0 \mathrm{c}$ & $0 \mathrm{c}$ & $0 \mathrm{c}$ & $0 \mathrm{~b}$ & $0 \mathrm{c}$ & $0 \mathrm{c}$ & $0 \mathrm{~b}$ & $0 \mathrm{~b}$ \\
Tetyda & $8 \mathrm{~b}$ & $2 \mathrm{c}$ & $5 \mathrm{c}$ & $2 \mathrm{c}$ & $1 \mathrm{~b}$ & $2 \mathrm{c}$ & $0 \mathrm{c}$ & $0 \mathrm{~b}$ & $0 \mathrm{~b}$
\end{tabular}

Explanations:

*favourable soil moisture

**soil drought

$\mathrm{a}, \mathrm{b}$ mean values followed by the same letters are not significantly different at the 0.05 level according Tukey's test

cultivar Desirée to high temperature during the growing season. Despite this, in current research on the biochemical and genetic tolerance of potato plants 'Desirée' is used as a cultivar with moderate resistance to heat stress (Hancock et al. 2014). In the earlier study of Rykaczewska (2004a) an increase in the number of tubers from 30 to $54 \%$ compared to
Fig. 3 Tuber deformations and sprouted tubers of tested cultivars depending on the soil moisture, period of high temperature and cultivar - in \% of total yield. Explanations: $H T$ high temperature, FSM favourable soil moisture; $S D$ soil drought; $a, b, c$ mean values followed by the same letters are not significantly different at the 0.05 level according Tukey's test

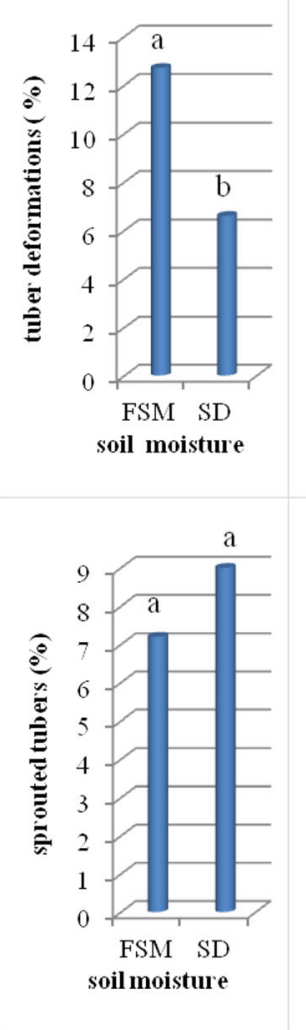

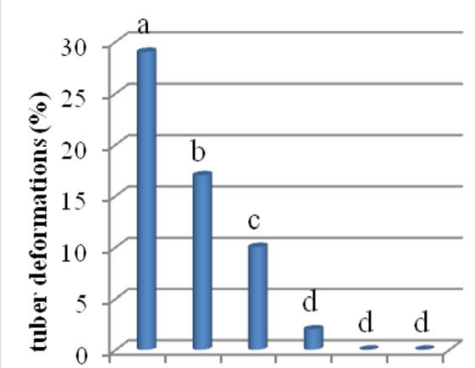
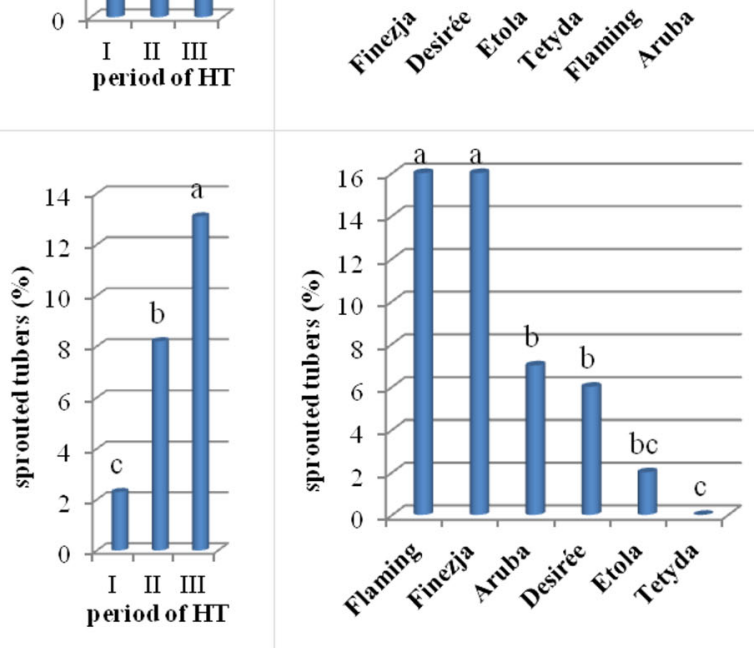
Table 10 Mass of sprouted tubers in final yield depending on cultivar in different periods of high temperature - in \% of total yield

\begin{tabular}{llll}
\hline Cultivar & \multicolumn{2}{l}{ Period of high temperature } \\
\cline { 2 - 4 } & I & II & III \\
\hline Aruba & $3 \mathrm{ab}$ & $7 \mathrm{~b}$ & $10 \mathrm{~b}$ \\
Desirée & $3 \mathrm{ab}$ & $5 \mathrm{~b}$ & $10 \mathrm{~b}$ \\
Etola & $0 \mathrm{~b}$ & $4 \mathrm{bc}$ & $1 \mathrm{c}$ \\
Finezja & $1 \mathrm{~b}$ & $15 \mathrm{a}$ & $34 \mathrm{a}$ \\
Flaming & $7 \mathrm{a}$ & $18 \mathrm{a}$ & $24 \mathrm{a}$ \\
Tetyda & $0 \mathrm{~b}$ & $0 \mathrm{c}$ & $0 \mathrm{c}$ \\
\hline
\end{tabular}

$\mathrm{a}, \mathrm{b}$ mean values followed by the same letters are not significantly different at the 0.05 level according Tukey's test

the control was found and also the presence of tubers chronologically younger. Those studies were performed, however, only with two cultivars with heat stress lasting for three weeks. In subsequent studies large differences among cultivar susceptibility to secondary tuberization due to the impact of high temperature $\left(32{ }^{\circ} \mathrm{C} / 25^{\circ} \mathrm{C}\right)$ during the growing season were demonstrated (Rykaczewska 2013b). In the study presented here a highly significant effect of the period of high temperature and cultivar on the tuber size in the yield was also found (Table 3, Fig. 2). Desirée cultivar stood out with the largest decrease in the size of the tubers, which was a consequence of the secondary tuberization.

\section{Tuber Physiological Defects}

High temperature occurring in subsequent stages of plant development had a negative effect on tuber defects and tubers' sprouting in the soil before harvest. In the case of tubers' deformation the largest share of these tubers in the final yield

Table 11 Correlation coefficients between investigated traits of plants and tuber yield influenced by high temperature in subsequent stages of plant development - depending on the level of soil moisture

\begin{tabular}{|c|c|c|}
\hline \multirow[t]{2}{*}{ Correlation } & \multicolumn{2}{|c|}{ Soil moisture } \\
\hline & FSM & SD \\
\hline Relative height of plants $\mathrm{x}$ relative yield & $-0.89 *$ & -0.67 \\
\hline Performance index of PS II x relative yield & $-0.99 * *$ & $-0.97 * *$ \\
\hline $\begin{array}{l}\text { Relative height of plants } \mathrm{x} \text { relative individual } \\
\text { tuber size }\end{array}$ & -0.79 & $-0.93 * *$ \\
\hline $\begin{array}{l}\text { Relative yield } \mathrm{x} \text { tuber physiological deformations } \\
\text { in total yield }\end{array}$ & $-0.95 * *$ & $-0.99 * *$ \\
\hline Relative yield $\mathrm{x}$ sprouted tubers in total yield & $+0.99 * *$ & $+0.98^{* *}$ \\
\hline
\end{tabular}

\footnotetext{
Explanations:

*favourable soil moisture

$* *$ soil drought

$* * P<0.01 ; * P<0.05$
}

occurred when high-temperature stress was applied in the I period (the second part of June) (Fig. 3, Table 9). The reaction of cultivars was significantly differentiated. In the control there were no the tubers with physiological defects. Results of the experiment obtained by Rykaczewska (2013b) are similar. However, Levy (1985) show that a single treatment of high temperatures during early stages of tuber development caused a lower percentage of misshapen tubers. This indicates that studies of this phenomenon require a larger number of cultivars and a more precise determination of the plant development stage at the beginning of the impact of heat stress. Here we demonstrated that soil moisture favourable for plant growth in the first periods of heat stress was significantly more conducive to the physiological deformations of tubers such as elongated tubers, bottlenecks, second growth (chaintuberization) and gemmations than drought. The results of an experiment conducted by Bodlaender et al. (1964) also clearly show that high temperatures induce second-growth in potato tubers. In the case of sprouting tubers in the soil before harvest, the response of plants to high temperature was also significantly dependent on treatment time but the biggest negative impact had a place when high-temperature stress was applied in the III period (the second part of July) (Fig. 3, Table 10). Soil moisture had no significant effect. Similarly, according to Bodlaender et al. (1964) high temperature can 'break' dormancy and drought did not induce or promote sprouting. In our experiment the reaction of cultivars was differentiated.

\section{General Remarks}

The significant correlations between investigated traits of plants and tuber yield influenced by high temperature in subsequent stages of plant development confirm the negative, very strong effects of high temperature during the growing season on yielding and tuber physiological deformations in total yield of tested potato cultivars (Table 11). It was also found a significant positive correlation between relative yield and sprouted tubers in the yield.

\section{Conclusion}

Our studies on the impact of high temperature on the development of potato confirm the view that its productivity is greatly reduced at temperatures higher than the optimum temperatures. It was demonstrated here, however, that potato cultivars' response to high temperature during the growing season is dependent on the growth stage, in which the temperature acts on the plants. The earlier it occurs, the more negative its impact on the growth and total yield of potatoes. Here we show that sustained for two weeks, the combined heat and drought stress which affects potato plants during the flowering 
period may reduce the yield of potato cultivars by over $35 \%$. It is also a cause of secondary tuberization. Here we show that seemingly mild heat stress acting on the plant for a period of two weeks under favorable soil moisture conditions may cause an increase in the height of the aboveground part in relation to control, and a small, just a few percent, decrease in yield. However, it seems to be the most harmful due to the presence of the tubers chronologically and physiologically younger in the crops. This phenomenon is highly disadvantageous in consumer use of the potato. In this study the high tolerance of cultivar Desirée to the heat stress during the growing season has not been confirmed. This cultivar was characterized by the relatively high tolerance of the aboveground part of plants to high temperature, but also a tendency to secondary tuberization and a decrease in the size of tubers in the total yield. The results obtained in this study indicate that among the tested cultivars 'Tetyda' was the most tolerant to high temperature acting on the plants during the growing season. This cultivar was characterized by a relatively small decrease in the total yield and tuber size in relation to control, by a low level of tuber deformations and lack of tendency for sprouting in the soil before harvest. A similar reaction was seen in cultivar Finezja. Our research shows that the total yield is not the only indicator of potato tolerance to high temperatures during the growing season, but the assessment should also take into account the occurrence of secondary tuberization and physiological defects of tubers.

Acknowledgements The author offers special thanks for the valuable technical assistance of A. Gajos during the whole period of growing season.

Open Access This article is distributed under the terms of the Creative Commons Attribution License which permits any use, distribution, and reproduction in any medium, provided the original author(s) and the source are credited.

\section{References}

Ahn, Y.J., K. Claussen, and J.L. Zimmerman. 2004. Genotypic differences in the heat-shock response and thermotolerance in four potato cultivars. Plant Science 166: 901-911.

Benoit, G.R., C.D. Stanley, W.J. Grant, and D.B. Torrey. 1983. Potato top growth as influenced by temperatures. American Potato Journal 60: 489-501.

Birch, P.R.J., G. Bryan, B. Fenton, E. Gilroy, I. Hein, J.T. Jones, A. Prashar, M.A. Taylor, L. Torrance, and I.K. Toth. 2012. Crops that feed the world 8: Potato: are the trends of increased global production sustainable? Food Security 4: 477-508.

Bodlaender, K.B.A. 1963. Influence of temperature, radiation and photoperiod on development and yield. In Growth of the potato, ed. J.D. Ivins and F.L. Milthorpe, 199-210. London: Butterworths.

Bodlaender, K.B.A., C. Lugt, and J. Marinus. 1964. The induction of second-growth in potato tubers. European Potato Journal 7: 57-71.
De Temmerman, L., A. Hacour, and M. Guns. 2002. Changing climate and potential impacts on potato yield and quality 'CHIP': Introduction, Aims and Methodology. European Journal of Agronomy 17: 233-242.

EPCD 2008. European Potato Cultivars Database. http://www. Europotato.org.

Ewing, E.E. 1981. Heat stress and tuberization stimulus. American Potato Journal 58: 31-49.

Gawrońska, H., R.B. Dwelle, and M.K. Thornton. 1992. Influence of heat stress on dry matter production and photoassimilate partitioning by four potato clones. American Potato Journal 69: 653-665.

Hancock, R.D., W.L. Morris, L.J.M. Ducreux, J.A. Morris, M. Usman, S.R. Verrall, J. Fuller, C.G. Simpson, R. Zhang, P.E. Hedley, and M.A. Taylor. 2014. Physiological, biochemical and molecular responses of the potato plant to moderately elevated temperature. Plant, Cell and Environment 37: 439-450.

Haynes, K.G., F.L. Haynes, and W.R. Henderson. 1989. Heritability of specific gravity of diploid potato under high-temperature growing conditions. Crop Science 29: 622-625.

Hijmans, R.J. 2003. The effect of climate change on global potato production. American Journal of Potato Research 80: 271-280.

Jefferies, R.A. 1992. Effects of drought on chlorophyll fluorescence in potato (Solanum tuberosum L.). I. Plant water status and the kinetics of chlorophyll fluorescence. Potato Research 35: 25-34.

Kalaji, H.M., R. Carpentier, S.I. Allakhverdiev, and K. Bosa. 2012. Fluorescence parameters as early indicators of light stress in barley. Journal Of Photochemistry and photobiology $B$ 112: $1-6$.

Kooman, P.L., and A.J. Haverkort. 1995. Modeling development and growth of the potato crop influenced by temperature and daylength. In Potato Ecology and Modeling of Crop under Conditions Limiting Growth, ed. A.J. Haverkort and D.K.L. MacKerron, 41-59. Dordrecht: Kluwer Academic Publishers.

Krauss, A., and H. Marschner. 1984. Growth rate and carbohydrate metabolism of potato tubers exposed to high temperatures. Potato Research 27: 297-303.

Lafta, A.H., and J.H. Lorenzen. 1995. Effect of high temperature on plant growth and carbohydrate metabolism in potato. Plant Physiology 109: 637-643.

Levy, D. 1985. The response of potatoes to a single transient heat or drought stress imposed at different stages of tuber growth. Potato Research 28: 415-424.

Levy, D. 1986a. Genotype variation in the response of potatoes (Solanum tuberosum L.) to high ambient temperatures and water deficit. Field Crops Research 15: 85-96.

Levy, D. 1986b. Tuber yield and tuber quality of several potato cultivars as affected by seasonal high temperature and by water deficit in a semi-arid environment. Potato Research 29: 95-107.

Levy, D., and R.E. Veilleux. 2007. Adaptation of potato to high temperature and salinity - a review. American Journal of Potato Research 84: 487-506.

Levy, D., E. Kastenbaum, and Y. Itzhak. 1991. Evaluation of parents and selection for heat tolerance in the early generations of a potato (Solanum tuberosum L.) breeding program. Theoretical and Applied Genetics 82: 130-136.

Lichtenthaler, H.K., and J.A. Miehé. 1997. Fluorescence imaging as a diagnostic tool for plant stress. Trends in Plant Science 2(8): 316-320.

Marinus, J., and K.B.A. Bodlaender. 1975. Response of some potato varieties to temperature. Potato Research 18: 189-204.

Mauromicale, G., A. Ierna, and M. Marchese. 2006. Chlorophyll fluorescence and chlorophyll content in field-grown potato as affected by nitrogen supply, genotype, and plant age. Photosynthetica 44: 76-82.

Rykaczewska, K. 1993. Effect of temperature during growing season and physiological age of minitubers on potato plant development and yield. Bulletin Potato Institution 42: 39-46. 
Rykaczewska, K. 2004a. Effect of high temperature during vegetation on potato (Solanum tuberosum L) yield, period of tuber dormancy and seed tuber yielding ability. I. Plant development and yield. Advance Agriculture Science 496: 185-198.

Rykaczewska, K. 2004b. Effect of high temperature during vegetation on potato (Solanum tuberosum L.) yield, period of tuber dormancy and seed tuber yielding ability. II. Tuber dormancy duration. Advance Agriculture Science 496: 199-206.

Rykaczewska, K. 2004c. Effect of high temperature during vegetation on potato (Solanum tuberosum L.) yield, period of tuber dormancy and seed tuber yielding ability. III. Value of seed tuber yielding. Advance Agriculture Science 496: 207-216.

Rykaczewska, K. 2013a. Assessment of potato mother tubers vigour using the method of accelerated ageing. Plant Protection Science 16: 171182.

Rykaczewska, K. 2013b. The impact of high temperature during growing season on potato cultivars with different response to environmental stresses. American Journal Plant Science 4: 2386-2393.

SAS Institute Inc. 2004. SAS. 9.1. Companion for Windows. Cary: SAS Publishing, SAS Institute Inc.
Struik, P.C., J. Geertsema, and C.H.M.G. Custers. 1989a. Effect of shoot, root and stolon temperature on the development of the potato ((Solanum tuberosum L) plant. I. Development of the haulm. Potato Research 32: 133-141.

Struik, P.C., J. Geertsema, and C.H.M.G. Custers. 1989b. Effect of shoot, root and stolon temperature on the development of the potato ((Solanum tuberosum L) plant. III. Development of tubers. Potato Research 32: 151-158.

Tremblay, N., Z. Wang, and Z.G. Cerovic. 2012. Sensing crop nitrogen status with fluorescence indicators. A revue. Agronomy for Sustainable Development 32: 451-464.

Van Dam, J., P.L. Kooman, and P.C. Struik. 1996. Effects of temperature and photoperiod on early growth and final number of tubers in potato (Solanum tuberosum L). Potato Research 39: 51-62.

Veilleux, R.E., M.M. Paz, and D. Levy. 1997. Potato germplasm development for warm climates: genetic enhancement of tolerance to heat stress. Euphytica 98: 83-92.

Wahid, A., S. Gelani, M. Ashraf, and M.R. Foolad. 2007. Heat tolerance in plants: an overview. Environmental and Experimental Botany 61: 199-223. 